\title{
THE NOTION, CLASSIFICATION AND IMPORTANCE OF GOODS CLASSIFICATION IN THE LIGHT OF THE NEW CIVIL REGULATIONS OF REPUBLIC OF MOLDOVA
}

\author{
Viorica Ursu*, ORCID ID: 0000-0003-4194-4799, \\ Natalia Chiriac, ORCID ID: 0000-0002-1189-2273 \\ Technical University of Moldova,168, Ștefan cel Mare bd.,Chișinău, Republic of Moldova \\ *Corresponding author: Viorica Ursu, viorica.ursu@dp.utm.md
}

Received: 04. 12. 2021

Accepted: 05. 17. 2021

\begin{abstract}
Any natural or legal person has a heritage, i.e. a set of rights and obligations that are assessable in money or in other words, with economic value. The rights, obligations and goods to which they refer may be considered individually or as a legal universality belonging to a person. The goods are, without any doubt, the basis of the social wealth of any country and any society. The economic relations are mostly the relations about certain goods. Once they have acquired a legal form, they do not change their content, keeping the same object - goods. Therefore, the correct reflection of the place and role of goods in social relations is essential for the efficient management of the country's economy.According to the unanimous opinion of the legislator, theorists and practitioners, goods are one of the main objects of civil law. Thus, this article represents a synthesis that analyzes the notion of goods, as well as their classification and importance in the new regulation of the Republic of Moldova's Civil Code. This research is also important due to the fact that the new changes are related to some categories of new goods, but also the completion of the existing ones, which were not found in the previous rules, but which were introduced due to the development of new social relations and new categories of goods that have appeared in our society.
\end{abstract}

Keywords: goods, work, heritage, asset, heritage right, economic value.

Adnotare. Orice persoană fizică sau juridică are un patrimoniu, adică un ansamblu de drepturi şi obligaţii care sunt evaluabile în bani sau altfel spus, cu valoare economică. Drepturile, obligaţiile şi bunurile la care se referă acestea pot fi luate în considerare în mod individual sau ca o universalitate juridică aparţinând unei persoane. La rândul său bunurile, constituie, fără îndoială, baza bogăției sociale a oricărei țări și a oricărei societăți. Relațiile economice sunt în cea mai mare parte relații despre anumite bunuri. După ce au dobândit o formă juridică, nu își schimbă conținutul, păstrând același obiect - bunuri. Prin urmare, reflectarea corectă a locului și rolului bunurilor în relațiile sociale este esențială pentru gestionarea eficientă a economiei țării. Conform opiniei unanime a legiuitorului, a 
teoreticienilor și a practicienilor, bunurile reprezintă una dintre principalele obiecte din dreptul civil. Astfel, prezentul articol reprezintă o sinteză care pune în discuţie noţiunea de bun, cât şi clasificarea şi importanţa bunurilor în noua reglementare a CC a RM. Această cercetare este importantă şi datorită faptului, că noile modificări țin de unele categorii de bunuri noi, dar şi completarea celor deja existente, care nu s-au regăsit în normele anterioare, dar care au fost introduse datorită dezvoltării noilor relaţii sociale şi noilor categorii de bunuri apărute în societatea noastră.

Cuvinte cheie: bun, lucru, patrimoniul, activul patrimonial, drept patrimonial, valoare economică.

1. Introducere. În raporturile juridice patrimoniale, conduita părţilor se referă adesea la lucruri. De regulă, însă, lucrul este luat în considerare ca obiect derivat al raportului juridic civil. Astfel, bunurile constituind doar un obiect material al acestei acţiuni sau inacţiuni. Bunurile sunt numite şi obiecte externe al raportului juridic civil. Deşi majoritatea obiectelor derivate ale raportului juridic civil sunt bunurile, acestea nu sunt unice, ca ex: anumite valori personale nepatrimoniale ca imaginea, reputaţia, operele literare, artistice, ştiinţifice, rezultatele creaţiei intelectuale, serviciile [1, p. 235].

2. Noţiunea de bun. Într-un prim înţeles, termenul bun desemnează orice lucru cu privire la care pot exista drepturi (şi obligaţii) patrimoniale. Într-un al doilea înţeles, mai larg, termenul bun desemnează orice element al activului patrimonial al unei persoane; cu alte cuvinte, bunul, în sens larg, se referă nu numai la lucruri, ci şi la drepturile privitoare la acele lucruri [2, p. 209].

Bunul, în sens restrâns, reprezintă valoarea economică ce este utilă pentru satisfacerea nevoilor materiale şi spirituale ale omului şi care este susceptibilă de apropriere (însuşire) sub forma drepturilor patrimoniale [3, p. 97].

Codul civil al RM, în art. 455 alin. (1), dispune că „bunurile sunt toate lucrurile susceptibile apropierii individuale sau colective și drepturile patrimoniale". În sensul atribuit de legiuitor termenului bun din articolul nominalizat, acesta include orice element al activului patrimonial al persoanei, adică atât lucrurile și animalele, cât și drepturile asupra lor sau, altfel spus, atât lucrurile, cât și drepturile patrimoniale care pot fi reale și obligaționale. De exemplu, bunuri sunt lucrurile care au existență materială și valoare economică, operele științifice, literare, artistice, invențiile etc. dacă au valoare economică și sunt susceptibile de drepturi patrimoniale, drepturi de creanță[1, p. 236 - 237].

Prin urmare, legiuitorul, în categoria de bunuri a inclus atât lucruri, cât și drepturile patrimoniale. După cum se poate observa, CC RM face distincţie între bun şi lucru [4, p. 39]: Lucruri sunt obiectele corporale în raport cu care pot exista drepturi şi obligaţii civile.Corelația dintre bun și lucru, conform dispozițiilor art.455, constă în faptul că bunul este genul, iar lucrul este specia. În majoritatea cazurilor, Codul civil utilizează termenul bun, chiar și atunci când, evident, este vorba de lucruri (de exemplu în art. 458 - 471, 482 - 496, 500 530, 536 - 542 etc.). Doar în câteva articole din cod este utilizat termenul lucru [5, art. 458, $460-461,1108]$.

Şi doctrina face distincţie între bun şi lucru. Putem defini astfel bunul ca fiind acea valoare economică ce este utilă pentru satisfacerea nevoilor materiale și spirituale ale omului şi este susceptibilă de apropriere sub forma dreptului patrimonial [6, p. 78]. 
În literatura de specialitate este susţinută ideea că prin lucru se înţelege „tot cea ce există în realitate sau numai în imaginaţie”, ori, „tot ceea ce se află în natură şi este perceptibil prin simţuri, adică tot ceea ce are o existenţă materială”.

Cu alte cuvinte, prin lucru se înţelege tot ceea ce se află în natură, fiind perceptibil prin simţuri, având o existenţă materială (terenuri, case, autoturisme etc.). Uzual, în drept, lucrurile iau numele de bunuri, avându-se în vedere avantajele pe care acestea le procură omului. De aceea, în majoritatea cazurilor se susţine că prin bunuri se înţeleg lucrurile utile omului pentru satisfacerea necesităţilor sale materiale şi culturale, susceptibile de apropiere, sub forma drepturilor patrimoniale [1. p. 237-238].

Pentru ca să devină bun în sens juridic, un lucru trebuie:

a) să fie util omului;

b) să aibă o valoare economică;

c) să fie susceptibil de apropiere, sub forma unor drepturi ce intră în componenţa unui patrimoniu, a unei persoane fizice, fie al uneia juridice. Numai în cazul în care lucrul întruneşte aceste trei calităţi se poate vorbi de bun în sensul dreptului civil.

Unele lucruri nu pot fi considerate bunuri, deoarece nu sunt susceptibile apropierii, după cum o cere şi art. 455 alin. (1). Atribuim acestei categorii de lucruri luna, soarele și alte corpuri cerești, care, deşi au valoare economică și sunt utile omului, nu pot fi apropiate prin folosire, prin ocupaţie sau prin alte mijloace. La fel, nu poate fi însuşit sau să se facă stăpân nici pe aerul atmosferic. Se poate pune totuşi o întrebare: oare "aerul din Carpaţi" comercializat in oraşe mari, unde aerul e foarte poluat, în recipienți speciali, nu sunt exemple potrivit cărora condiția referitoare la susceptibilitatea de a fi însușite, sub forma drepturilor patrimoniale, este relativă?

Probabil, unele dintre aceste lucruri cândva vor putea fi considerate bunuri în sensul dreptului civil. De exemplu, nu este exclus faptul că omul cândva va locui pe Lună sau pe alte planete, care, la momentul actual, nici nu sunt cunoscute [7, p. 92 - 93].

Astfel, un autor [8], pe buna dreptate, apreciază: “....aceste condiții sunt relative în timp și în spațiu și trebuie privite în perspectiva istorică, lucruri inutile la un moment dat pot deveni apoi utile (de pilda reciclarea deșeurilor), sau nesusceptibile de apropiere (ca spațiul cosmic de pilda) putând deveni, in viitor, obiecte ale unor drepturi (sub forma resurselor minerale extrase din alte corpuri cerești, sau a resurselor energetice oferite de vântul solar)".

În ultimul timp, se discută asupra faptului dacă organele omului pot fi considerate bunuri.

Aşadar, după părerea autoarei ruse Krasavcikova, organele şi ţesuturile umane reprezintă valori personale nepatrimoniale, în legătură cu care apar relaţii civile pe fundalul actului de donaţie şi transplant, iar după extragerea materialului biologic de la o persoană concretă acestea îşi pierd determinarea lor personal-individuală [9, p. 101].

Cea mai răspândită viziune este însă aceea conform căreia organele şi ţesuturile detaşate de organism se atribuie la categoria de bunuri limitate în circuitul civil [10, p. 87].

Corpul uman nu poate fi privit ca un bun şi nu poate face obiectul unui raport juridic patrimonial. Această concluzie se impune cu titlu de principiu general, chiar dacă nu este prevăzută expres în legislaţia în vigoare, dar ea poate fi dedusă din alin.(1) art.27 şi alin.(2) al art. 28 din Legea nr. 42 din 06.03.2008 [11]. 
Art. 44 al CC prevede expres că orice acte juridice care au ca obiect conferirea unei valori patrimoniale corpului uman, elementelor sau produselor sale sunt lovite de nulitate absolută, cu excepția cazurilor expres prevăzute de lege.

De asemenea, art.27 al Legii privind transplantul de organe, ţesuturi şi celule umane [11] interzice obţinerea de profituri financiare ca urmare a donării de organe, ţesuturi sau celule umane. Donarea şi transplantul de organe, ţesuturi şi celule nu pot constitui obiectul unei tranzacţii materiale.Se interzice popularizarea necesităţii transplantului de organe, ţesuturi şi/sau celule în scopul de a propune sau a obţine profituri financiare sau avantaje corespunzătoare.

În contextul dispoziţiilor art.455, se poate spune că orice lucru este un bun, dar nu orice bun este un lucru. Astfel, se confirmă o dată în plus corelaţia dintre aceşti doi termeni: de gen (bun) şi de specie (lucru) [7, p. 93].

Pornind de la conținutul art.455, bunul poate fi definit ca lucru față de care pot exista drepturi şi obligaţii patrimoniale şi care poate fi folosit în viaţa socială, precum şi ca drept patrimonial [7, p. 94].

Un loc aparte în Codul civil îl ocupă reglementările referitoare la animale. Art. 457 prevede: „Animalele nu sunt lucruri. Ele sunt ocrotite prin legi speciale. În privinţa animalelor se aplică dispoziţiile referitoare la lucruri, cu excepţia cazurilor stabilite de lege".

Din conţinutul acestei norme reiese că, deşi animalele nu pot avea calitatea de subiect de drept, ele nu sunt egalate cu lucrurile şi, în privinţa lor, se instituie reguli speciale de comportament al subiectelor de drept. De exemplu, o reglementare specială există în art. 517 alin. (3) din Codul civil, care prevede modalitatea de dobândire a dreptului de proprietate asupra bunului găsit. Această particularitate constă în faptul că dacă o persoană a dobândit, în conformitate cu art. 517 dreptul de proprietate asupra unui animal, fostul proprietar poate, în cazul în care se va constata existenţa unei afecţiuni în privinţa sa din partea animalului sau comportamentul crud al noului proprietar faţă de animal, să ceară restituirea acestuia[1, p. 239].

Legislația RM stabilește pedepse pentru cruzimea față de animale [12, art. 222 $;$; , art. 157].

Deşi animalele nu sunt considerate lucruri, totuşi, în ceea ce priveşte modul de dobândire, posesiune, folosinţă, dispoziţie sunt aplicabile regulile cu privire la lucruri, excepţie făcând cazurile prevăzute de lege. Prin urmare, şi asupra animalelor oamenii, în principiu, pot avea aceleaşi drepturi: dreptul de proprietate, dreptul de închiriere, dreptul de a le vinde, dona, a le da în folosinţă etc. [7, p.94].

3. Noţiunea de bun, în sensul art.1 din Protocolul nr.1 la Convenția Europeană a

Drepturilor Omului. Convenția nu dă nicio definiție a termenului bun, de aceea, elementele acestei noțiuni trebuie căutate în jurisprudența de la Strasbourg.

Se poate face o deducţie generală că termenul bunuri, aşa cum este utilizat în art. 1, acoperă trei mari categorii: drepturile reale, în sensul clasic al termenului, drepturile personale şi drepturile nemateriale [13, p. 476].

În plus, pentru a intra în domeniul de aplicare al art.1, un bun trebuie să corespundă unui anumit număr de criterii: el trebuie să fie suficient de individualizabil şi cuantifiabil şi să poată face obiectul unei transmiteri. De exemplu, un permis de conducere nu este un obiect de proprietate. El nu depinde de altfel, în dreptul francez, de regimul de drept comun de restituire a obiectelor sechestrate. Această afirmaţie trebuie totuşi nuanţată cu recunoaşterea pretoriană a bunurilor „nemateriale”. Anume din astfel de considerente 
Curtea de Casaţie a recunoscut „o valoare patrimonială” numărului de cod al unei cărţi bancare [13, p. 476].

În plus, un bun, în principiu, trebuie să fie actual şi să existe la momentul atingerii: nu poate fi vorba de un drept potenţial sau aleatoriu. Astfel, în cauza Van der Mussele, Curtea a estimat că nu puteau constitui un bun onorariile datorate unui avocat numit din oficiu şi pe care acesta nu le-a primit din cauza incapacităţii de plată a clientului său, acestea având în speţă un caracter viitor şi nesigur.

Cu toate acestea, se pare că nu mai este absolut necesar ca bunul să fie materializabil: o creanţa vizavi de stat este considerată un bun în sensul Convenţiei, soluţie adnotată de Curte privind creditul de TVA, speţă în care ea a considerat un bun „speranţa legitimă de a obţine rambursarea [de TVA plătită pe nedrept]"[1, p. 241].

Fosta Comisie a estimat că pentru a răspunde criteriilor din art.1, Prot. ad., bunul trebuie să aibă „o valoare nesupusă riscurilor vieţii economice”. Această decizie, de altfel izolată, este foarte criticabilă în măsura în care referinţa la „riscurile vieţii economice” este periculoasă, căci este aplicabilă tuturor bunurilor, fie reale (fluctuaţiile de pe piaţa imobiliară, deprecierea în timp a valorii unui vehicul) sau nemateriale (pachet de acţiuni a căror valoare în timp nu este niciodată fixă); anume cu ocazia unei speţe privind un portofoliu de valori mobiliare fosta Comisie va reveni la o jurisprudenţă total opusă, atitudine adoptată ulterior şi în cauza Lupuleţ c/României.

În schimb, un drept de proprietate stins sau pierdut prin prescripţie nu mai este un bun în sensul Protocolului nr.1: „Speranţa de a obţine recunoaşterea dreptului de succesiune asupra unui vechi drept de proprietate care nu este susceptibil de exercitare efectivă de mult timp (...) nu mai constituie un bun în sensul art. 1". În plus, dreptul de proprietate trebuie dovedit cu ajutorul unui titlu sau al unui alt mod de probă admis de legislaţia statului. De exemplu, în dreptul francez anumite documente administrative nu sunt suficiente pentru stabilirea proprietăţii, cum ar fi certificatul de înmatriculare a unui autovehicul, care doar atestă înmatricularea acestuia şi permite punerea sa în circulaţie [13, p. 477].

4. Clasificarea bunurilor. Varietatea bunurilor şi necesitatea stabilirii regimului lor juridic impun o clasificare a lor. Codul civil clasifică bunurile după cum urmează:

1. Bunuri aflate în circuitul civil, bunuri scoase din circuitul civil şi bunuri limitate în circuitul civil [5, art. 457];

2. Bunuri imobile şi bunuri mobile [5, art. 459];

3. Bunuri divizibile şi bunuri indivizibile [5, art. 466];

4. Bunuri principale şi bunuri accesorii [5, art. 467];

5. Bunuri fungibile şi bunuri nefungibile [5, art. 468];

6. Bunuri determinate individual şi bunuri determinate generic [5, art. 469];

7. Bunuri consumptibile şi bunuri neconsumptibile [5, art. 470];

8. Bunuri ale domeniului public şi bunuri ale domeniului privat [5, art. 471];

9. Universalităţi de bunuri [5, art. 472];

10. Bunurile frugifere şi bunuri nefrugifere [5, art. 473 - 474 (fructe şi produse)];

11. Conţinutul digital şi bunul digital [5, art. 477];

12. Bunurile corporale şi incorporale[5, art. 455];

13. Bunurile culturale mobile [5, art. 481]

14. Obiectele de proprietate intelectuală [5, art. 476]. 
4.1. După regimul circulaţiei juridice distingem: bunuri care se află în circuitul civil, bunuri care sunt supuse unui regim special de circulație și bunuri scoase din circuitul civil. Conform art.457 CC RM, „Bunurile pot circula liber, cu excepţia cazurilor când circulaţia lor este limitată sau interzisă prin lege".

a) Bunuri care se află în circuitul civil - sunt cele care pot face obiectul actelor juridice civile. De regulă, bunurile sunt în circuitul civil. Deci, legea (şi numai legea) trebuie să prevadă, în mod expres, excepţiile. Bunurile aflate în circuitul civil sunt toate bunurile alienabile, ce se pot urmări de creditori şi se pot dobândi şi pierde prin prescripţie. Din categoria bunurilor aflate în circuitul civil fac parte bunurile de consum, bunurile de uz casnic, gospodăresc.

b) Bunuri supuse unui regim special de circulaţie - acele bunuri care deşi se află în circuitul civil, totuşi, au un regim special de circulaţie în ce priveşte circulaţia lor, cu alte cuvinte, circulaţia acestora este limitată. Bunurile care sunt limitate în circuitul civil pot fi dobândite, deţinute, folosite şi înstrăinate în anumite condiţii prevăzute de lege. În principiu, restricţiile ce privesc circulaţia bunurilor se pot referi fie la subiecte de drept care pot dobândi şi înstrăina aceste bunuri, fie la condiţiile de încheiere a actelor juridice cu aceste bunuri. Aşa de exemplu, conform prevederilor art.7 din Legea cu privire la arme [14], permisul de procurare a armelor letale şi neletale supuse autorizării şi, după caz, permisul de armă se acordă persoanelor prevăzute în art.8 alin.(1) dacă nu se află în una din situaţiile specificate în alin. (2) din prezentul articol şi întrunesc cumulativ următoarele condiţii: au împlinit vârsta de 21 de ani; au absolvit un curs de instruire teoretică şi practică de mânuire a armei de foc, organizat de o persoană juridică acreditată în domeniu, în condițiile legii, cu excepţia personalului atestat din cadrul autorităților administraţiei publice care au competenţe în domeniul apărării naţionale, securităţii statului şi al ordinii publice; dispun de condiţ̧ii pentru asigurarea securităţii şi integrităţii armelor şi a muniţiilor; sunt apte din punct de vedere psihologic şi medical pentru a deţine şi a folosi arme şi muniţii; au calitatea impusă de lege, atestată prin documente prevăzute în normele de aplicare a prezentei legi, în funcţie de destinaţia armelor.

La fel, au o circulaţie limitată monumentele, adică bunurile ce fac parte din patrimoniul cultural, în conformitate cu Legea 1530/1993, materialele explozive, produsele şi substanţele toxice, obiectele de cult etc.

c) Bunuri scoase din circuitul civil - acele bunuri care nu pot face obiectul actelor juridice. Bunurile scoase din circuitul civil sunt inalienabile - nu pot fi înstrăinate. Sunt scoase din circuitul civil lucrurile care:

- prin natura lor, nu sunt susceptibile de apropiere, sub forma dreptului de proprietate sau a altor drepturi reale, cum ar fi: aerul, apele curgătoare, spaţiul cosmic;

- bunurile domeniului public în conformitate cu prevederile art.471;

- alte categorii de bunuri care prin lege sunt scoase din circuitul civil.

Importanţa acestei clasificări se manifestă în ceea ce priveşte valabilitatea actelor juridice civile sub aspectul obiectului lor. Astfel, nerespectarea prevederilor legale care supun unor condiţii actele juridice privitoare la anumite bunuri atrage, pe lângă nulitatea respectivelor acte, şi răspunderea contravențională sau penală [15, p. 45].

De exemplu, art. 290 din Codul penal [12] stabilește sancțiune penală pentru purtarea, păstrarea, procurarea, fabricarea, repararea sau comercializarea armelor de foc, precum şi sustragerea lor, cu excepţia armei de vânătoare cu ţeavă lisă, sau a muniţiilor fără autorizaţia corespunzătoare. Astfel, se pedepseşte cu amendă în mărime de la 650 la 950 
unităţi convenţionale sau cu muncă neremunerată în folosul comunităţii de la 180 la 240 de ore, sau cu închisoare de până la 3 ani.Aceleaşi acţiuni săvârşite de două sau mai multe persoane se pedepsesc cu închisoare de la 2 la 7 ani.

Art. 360 al Codului Contravențional [16] stabilește sancțiune contravențională pentruîncălcarea modului de comercializare şi/sau de înstrăinare a armelor letale sau neletale şi/sau a muniţiilor aferente. Astfel, comercializarea armelor letale sau neletale şi/sau a muniţiilor aferente persoanelor care nu sunt autorizate în modul stabilit de legislaţia în vigoare se sancţionează cu amendă de la 240 la 300 de unităţi convenţionale aplicată persoanei juridice cu privarea de dreptul de a desfăşura o astfel de activitate pe un termen de la 3 luni la un an. Iar încălcarea modului de înstrăinare a armelor letale sau neletale supuse autorizării şi/sau a muniţiilor aferente sau transmiterea acestora unei persoane neautorizate în modul stabilit de legislaţia în vigoare se sancţionează cu amendă de la 30 la 60 de unităţi convenţionale cu privarea de dreptul de deţinere sau port şi folosire a armei pe un termen de la 2 ani la 5 ani.

4.2. În funcţie de natura bunurilor şi calificarea dată de lege, distingem:bunuri mobile și bunuri imobile.

a) Bunurile imobile. Potrivit Dicționarului explicativ al limbii române, „bunurile imobile reprezintă lucruri care au o aşezare fixă, stabilă şi care, aşadar, nu pot fi mutate dintr-un loc în altul, fără să-şi piardă destinaţia iniţială sau identitatea" [17 ].

Codul Civil al Republicii Moldova nu conține definiția de „bunuri imobile”, însă art. 459 alin. (2) prevede: „Bun imobil se consideră terenul înregistrat în Registrul bunurilor imobile sub număr cadastral distinct”. Modificările operate la Codul civil au drept obiectiv revenirea la sistemul tradițional de a reglementa regimul bunurilor imobile, și anume, se revine la principiul că tot ce se află pe teren face parte din teren (superficies solo cedit) [18, p. 17]. În acest sens, se introduce regula că bun imobil se consideră terenul, iar construcţiile, lucrările, drumurile, alte amenajări de pe el fac parte componentă din teren (aceste reglementări se regăsesc în codurile civile europene). Astfel, proprietarul terenului cu construcţie nu poate vinde sau ipoteca construcţia, dar păstra terenul.

Art. 459 alin. (3) CC RM prevede: „Rămân bunuri imobile materialele separate în mod provizoriu de un teren, pentru a fi reîntrebuinţate, atât timp cât sunt păstrate în aceeaşi formă, precum şi părţile integrante ale unui bun imobil care sunt detaşate provizoriu de acesta dacă sunt destinate reamplasării. Materialele aduse pentru a fi întrebuinţate în locul celor vechi devin bunuri imobile".

Astfel, materialele separate în mod provizoriu de un teren atât timp cât sunt păstrate în aceeaşi formă, cum ar fi de exemplu cărămizile din ziduri cu condiţia că acestea să fie reîntrebuinţate în aceeaşi construcţie şi părţile integrante ale unui bun imobil care sunt detaşate provizoriu de acesta dacă sunt destinate reamplasării, de exemplu unele elemente ale construcţiilor care sunt separate pentru a fi întrebuinţate în altă construcţie. În cazul în care materialele vechi sunt înlocuite cu altele noi, atunci acestea preiau locul celor vechi şi deci devin bunuri mobile. Această calificare dată unor bunuri este o ficţiune legală necesară pentru a supune bunurile aceloraşi reguli ca şi pentru imobilul la care sunt ataşate $[19$, p. 336].

Constituie parte componentă a bunului imobil lucrurile și lucrările atașate permanent la teren, precum clădirile, construcțiile subterane (chiar dacă se extind asupra altor terenuri), obiectele acvatice separate, plantațiile prinse de rădăcini, roada neculeasă. 
Această regulă se aplică indiferent dacă aceste părți componente sunt sau nu sunt înregistrate în Registrul bunurilor imobile în mod separat [5, art. 460, alin. (1)].

Totodată, nu constituie parte componentă a bunului imobil:

- clădirile și alte lucruri și lucrări atașate permanent la teren, care sunt construite pe terenul altuia pe baza unui drept de superficie, precum și lucrurile atașate la teren pentru un scop temporar [5, art. 460, alin. (2)];

- rețelele de utilitate sau lucrările de utilitate amplasate pe bunul imobil care au fost construite de către un terț pe baza unui drept de superficie sau în privința cărora proprietarului bunului imobil îi incumbă obligația legală de a le tolera [5, art. 460, alin. (3)].

Clădirile și alte lucruri și lucrări atașate permanent la teren care rămân pe teren la stingerea dreptului de superficie devin parte componentă a terenului [5, art. 460, alin. (5)].

Constituie parte componentă a clădirii lucrurile și lucrările din care clădirea este construită sau care sunt atașate ei în mod permanent și care nu pot fi separate fără a deteriora în mod substanțial clădirea sau lucrul ori lucrarea supusă separării [5, art. 461, alin. (1)].

Lucrul sau lucrarea atașată la o clădire pentru un scop temporar nu este parte a acelei clădiri [5, art. 461, alin. (2)].

Constituie bun imobil unitatea în condominiu împreună cu cota-parte corespunzătoare din dreptul de proprietate sau de superficie asupra terenului, părților din clădire altele decât unitățile și altor părți comune ale condominiului [5, art. 462, alin. (1)].

Unitatea și cota-parte corespunzătoare din dreptul asupra părților comune nu pot fi înstrăinate sau grevate decât împreună [5, art. 460, alin. (2)].

Proprietatea terenului se întinde și asupra subsolului și a spațiului de deasupra terenului, cu respectarea limitelor legale [5, art. 463, alin. (1)].

În condițiile legii, proprietarul poate face, deasupra și în subsolul terenului, toate construcțiile, plantațiile și lucrările pe care le găsește de cuviință și poate trage din ele toate foloasele pe care acestea le-ar produce. El este ținut să respecte, în condițiile și în limitele determinate de lege, drepturile terților asupra resurselor minerale ale subsolului, izvoarelor și apelor subterane, lucrărilor și instalațiilor subterane și altora asemenea [5, art. 463, alin. (2)].

Apele de suprafață și albiile acestora aparțin proprietarului terenului pe care se formează sau curg, în condițiile prevăzute de lege. Proprietarul unui teren are, de asemenea, dreptul de a apropria și de a utiliza, în condițiile legii, apa izvoarelor și a lacurilor aflate pe terenul respectiv, apa freatică, precum și apele pluviale [4, art. 463, alin. (3)].

Conform art. 464 CC RM nou, „Prevederile referitoare la bunurile imobile şi mobile se aplică în modul corespunzător şi drepturilor reale asupra acestor bunuri”. Bunurile imobile, grevările acestor drepturi, apariţia, modificarea şi încetarea lor sunt supuse înregistrării de stat. Cadastrul bunurilor imobile asigură recunoaşterea publică a dreptului de proprietate şi a altor drepturi patrimoniale asupra bunurilor imobile, cât şi ocrotirea de stat a acestor drepturi. Drepturile reale asupra bunurilor imobile vor lua naştere doar în cazul în care vor fi înregistrate în Registrul bunurilor imobile. Aceeaşi regulă va fi aplicabilă şi în cazurile de modificare şi încetare a acestor drepturi. Drept consecinţă, drepturile reale asupra bunurilor reale vor fi opozabile terţilor doar dacă au fost înregistrate în Registrul bunurilor imobile. Organul care efectuează înregistrarea este obligat să elibereze, în termen de 3 zile, oricărei persoanei fizice care s-a legitimat şi a depus a cerere scrisă sau persoanei juridice care l-a 
sesizat oficial informaţiile solicitate despre toate drepturile înregistrate asupra oricărui bun imobil [5, art. 464].

Totodată, prin lege, la categoria de bunuri imobile pot fi raportate şi alte bunuri [5, art. 459 alin. (4)].Codul civil, prin prevederea din acest articol, admite posibilitatea răsfrângerii regimului juridic al bunurilor imobile şi asupra altor categorii de bunuri, dar cu condiţia ca acest lucru să fie expres prevăzut de lege.

Codul funciar al RM, în art. $2^{1}$ stipulează că constituie bunuri imobile: „sectoarele de teren şi obiectele aferente acestora (solul, bazinele de apă închise, pădurile, plantaţiile multianuale, clădirile, construcțiile, edificiile etc.), strămutarea cărora este imposibilă fără a cauza pierderi directe destinaţiei lor" [20, art. 2, alin. (1)].

Legea cadastrului bunurilor imobile [21] nu diferențiază bunurile imobile de cele mobile, însă în art.4 se enumeră obiectele înregistrării în cadastru. Astfel, la categoria bunurilor imobile ca obiect al înregistrării sunt atribuite: terenurile; clădirile şi construcţiile legate solid de pământ; apartamentele şi alte încăperi izolate. De asemenea, în Registrul bunurilor imobile pot fi înregistrate locurile de parcare din clădire, delimitate în conformitate cu instrucţiunile pentru executarea lucrărilor cadastrale, porţiunile de subsol, obiectivele acvatice separate, precum şi plantaţiile prinse de rădăcini (plantaţiile perene) înfiinţate în conformitate cu normele stabilite de legislaţie.

Legea cu privire la formarea bunurilor imobile [22], în articolul 8 enumeră bunurile imobile care pot/nu pot fi formate ca obiect independent de drept. Astfel, pot fi formate ca obiect independent de drept:

a) terenurile cu sau fără construcţii;

b) construcţiile, inclusiv cele nefinalizate;

c) apartamentele;

d) încăperile izolate, dacă sunt respectate condiţiile art. 7 al legii.

Totodată, nu pot fi formate ca obiect independent de drept:

a) încăperile din apartamente sau case individuale care nu corespund condiţiilor prevăzute de art. 7 al legii;

b) construcţiile auxiliare ale căror funcţii sunt legate direct de construcţia principală;

c) instalaţiile inginereşti;

d) anexele de deservire a gospodăriei, dacă este imposibilă specificarea dependenţei lor funcţionale sau dacă folosirea lor nu este definită;

e) gardurile, pereţii, bornele de hotar, alte instalaţii ale căror funcţii sunt legate direct de teren sau de construcţia principală.

Observăm că o astfel de clasificare în legislația RM este întâlnită pentru prima dată.

Codul fiscal al RM [23], în art. 276, pct. 2, dă următoarea definiție a „bunurilor imobiliare" - terenurile, clădirile, construcţiile, apartamentele şi alte încăperi izolate, a căror strămutare este imposibilă fără cauzarea de prejudicii destinaţiei lor.

b) Bunuri mobile. Art. 459 alin. (5) CC RM nou: „Bunurile care nu sunt raportate la categoria de bunuri imobile, inclusiv banii, valorile mobiliare și alte titluri de valoare, sunt considerate bunuri mobile".

Importanța clasificării bunurilor în mobile sau imobile constă în stabilirea regimului juridic al bunurilor imobile şi al celor mobile, care este diferit [24]. Astfel, în dreptul civil:

- în ceea ce priveşte înstrăinarea lor, formele de publicitate se aplică în principal actelor juridice, având ca obiect bunuri imobile; la înstrăinarea bunurilor imobile se cere respectarea formei autentice [5, art. 323]; 
- în ceea ce privește garanțiile reale, bunurile mobile pot forma obiectul unui gaj sau al unei garanții reale mobiliare, iar bunurile imobile pot forma obiectul unei ipoteci;

- în ceea ce privește prescripția extinctivă, acțiunea în revendicare se prescrie diferit după cum priveşte un bun mobil sau imobil;

- în cazul bunurilor imobile, dreptul de proprietate se dobândeşte la data înscrierii în Registrul bunurilor imobile, cu excepţiile prevăzute de lege;

- renunţarea la dreptul de proprietate asupra bunurilor imobile se face printr-o declaraţie autentificată notarial şi înscrisă în Registrul bunurilor imobile;

- pentru actele de dispoziţie asupra bunurilor imobile proprietate comună în devălmăşie este necesar acordul scris al tuturor coproprietarilor devălmaşi;

- dacă bunurile succesorale se află în diferite locuri, cel al deschiderii succesiunii va fi considerat locul unde se află partea cea mai valoroasă a bunurilor imobile;

- bunurile imobile se bucură de o protecţie legală mai puternică; unele bunuri mobile (nave, aeronave, fondul de comerţ etc.) au un regim juridic asemănător imobilelor [25];

- bunurile imobile proprietate comună a soţilor pot fi înstrăinate numai cu consimţământul expres al ambilor soţi, în timp ce în cazul înstrăinării bunurilor mobile funcţionează regula mandatului tacit reciproc între soţi.

- o condiţie importantă la înstrăinarea bunurilor imobile este capacitatea deplină de exerciţiu a înstrăinătorului;

- acţiunea în materie imobiliară este de competenţa instanţei locului situării bunului, în timp ce în materie mobiliară competenţa este a instanţei domiciliului pârâtului;

- în dreptul internaţional privat, legea aplicabilă în materie imobiliară este legea statului în care se găsesc bunurile (lex rei sitae), iar în materie mobiliară, în privinţa anumitor categorii de bunuri (nave, aeronave) se aplică legea statului sub al cărui pavilion navighează, iar mărfurile în tranzit sunt supuse legii locului de expediţie;

- înstrăinarea anumitor bunuri imobile este supusă, uneori, unor cerinţe mai riguroase (terenul agricol nu poate fi înstrăinat decât unui cetățean al RM);

- executarea silită este supusă unor reguli diferite, după cum se urmărește un bun mobil sau imobil;

- în situaţia unirii unui bun imobil cu un bun mobil, bunul imobil este considerat bunul principal.

Importanta aceste clasificări rezultă din regimul juridic aplicat în mod diferit la bunurile mobile şi imobile. Ca exemplu:

a) Regimul înstrăinării bunurilor. Pentru bunurile imobile, pentru actele de înstrăinare legiuitorul stabileşte forma scrisă şi autentificată notarial, pentru bunurile mobile - nu este stabilit același lucru în legislaţie, astfel părţile determină de comun acord forma contractului.

b) Dovada proprietăţii. Dacă vorbim de bunul mobil, atunci acesta se prezumă că aparţine posesorului bunului, adică legea nu cere nişte condiţii de opozabilitate. Referitor la bunul imobil, dovada proprietăţii se face doar prin acte doveditoare.

c) Momentul transmiterii dreptului de proprietate. Dreptul de proprietate asupra unui bun mobil se consideră dobândit din momentul din care dobânditorul a intrat în posesia asupra bunului. Pentru bunurile imobile, momentul dobândirii dreptului de proprietate este raportat la momentul înscrierii dreptului in registrul bunurilor imobile 
(excepţii, ca ex. moştenirea, unde dreptul de proprietate se dobândeşte la momentul deschiderii moştenirii etc).

d) Exercitarea drepturilor comune. Dacă ne referim la bunul mobil ce se află în proprietatea comună în devălmăşie, în cazul când unul dintre soţi doreşte să dispună de acest bun, o face doar cu acordul expres al celuilalt soţ. În cazul înstrăinării bunului mobil, în cadrul proprietăţii comune în devălmăşie, nu este necesar acest acest acord expres, ca la bunurile imobile, fiindcă acordul se prezumă.

4.3. După cum pot fi sau nu împărţite fără să îşi schimbe destinaţia, bunurile se clasifică în divizibile şi indivizibile.

a) Bunul divizibileste cel care poate fi partajat în natură fără a i se schimba destinaţia economică [5, art. 466 alin. (1)]. De exemplu, o cantitate de 100 l vin poate fi aşezată în butoaie de diferite mărimi; un cupon de stofă măsurând 100 m poate fi împărţit în cupoane mai mici etc.). Divizibilitatea rezultă din natura lucrului [25, p. 113].

Urmează să precizăm că divizibilitatea bunurilor trebuie să fie privită sub două aspecte: sub aspect fizic şi sub aspect juridic. Sub aspect fizic sunt divizibile numai bunurile corporale, dat fiind faptul că materia în sine este întotdeauna divizibilă. Divizibilitatea fizică presupune existenţa a trei condiţii:

- părţile din care era compus bunul să posede calităţile individuale ale întregului;

- Părţile, în urma diviziunii, să rămână proprii pentru destinaţia economică pe care o avea întregul;

- părţile să nu sufere o depreciere valorică disproporţionată[1, p. 250].

b) Bunul indivizibil este cel care nu poate fi împărţit în mai multe fragmente, părţi, bucăţi etc., fără a i se schimba destinaţia (de ex.: o haină, o maşină de scris, un calculator, un tablou, un animal viu etc.). Este indivizibil bunul ale cărui părţi, în urma divizării, pierd calităţile şi destinaţia lui [5, art. 466 alin. (2)].

Indivizibilitatea unui lucru rezultă din natura lui. Pentru aplicarea acestei clasificări se poate utiliza atât un criteriu obiectiv (însuşirile naturale ale lucrului), cât şi un criteriu subiectiv fondat pe voinţa părţilor exprimată în actul încheiat.

Prin act juridic, un bun divizibil poate fi considerat indivizibil [5, art. 466 alin. (3)].

Această clasificare are importanţă în materia partajului şi a obligaţiilor cu pluralitate de subiecte.

Astfel, în cazul partajului, întrucât bunul indivizibil nu poate fi fracţionat, el va fi atribuit unuia dintre copărtaşi sau va fi scos în vânzare prin licitaţie, iar preţul obţinut va fi împărţit între copărtaşi.

De asemenea, bunul indivizibil care formează obiectul unei obligaţii cu mai multe subiecte determină o indivizibilitate naturală, aşa încât, după caz, fiecare creditor poate cere întreaga prestaţie sau fiecare debitor este ţinut să execute întreaga prestaţie [26, p. 84].

4.4. În funcţie de corelaţia dintre ele, bunurile se clasifică în principale și accesorii.

a) Bunuri principalesunt acele bunuri care au o existenţă de sine stătătoare, 0 destinaţie economică proprie, adică pot fi folosite independent, fără a servi la întrebuinţarea unui alt bun[2, p. 338]. Toate celelalte bunuri sunt principale [5, art. 467 alin. (1)].

b) Bunuri accesorii. Bunul destinat în mod permanent întrebuinţării economice unui alt bun (principal) şi legat de acesta prin destinaţie comună este un bun accesoriu atât timp, cât satisface această întrebuinţare [5, art. 467 alin. (1)]. 
Bunurile accesorii sunt acele bunuri care sunt destinate să servească la întrebuinţarea altor bunuri principale [19, p. 338]. Ca exemple de bunuri accesorii, cităm: cheia pentru lacăt, cureaua pentru ceas, coperta pentru caiet, antena de la televizor, arcuşul de la vioară, beţele pentru ski etc. Codul civil, în art.467 alin.(1) CC RMatribuie două caractere bunurilor accesorii, şi anume:

- existenţa unei legături economice între bunul accesoriu şi principal;

- bunul accesoriu trebuie să fie destinat în mod permanent întrebuinţării economice a bunului principal.

Starea de accesoriu poate rezulta din raportul juridic care se află în dependenţă faţă de altul, ca de exemplu în cazul raportului de garanţie (dreptul de gaj) sau din natura lucrurilor.

Conform art. 467 alin. (2)CC RM, „destinaţia comună poate fi stabilită numai de proprietarul ambelor bunuri dacă în contract nu este prevăzut altfel".

Pentru a fi în prezenţa bunurilor principale şi accesorii trebuie ca ambele aceste bunuri să fie în proprietatea uneia şi aceleiaşi persoane. Aceasta înseamnă că bunul principal şi bunul accesoriu trebuie să aibă acelaşi proprietar [19, p. 338].

Pentru a stabili dacă un bun este accesoriu sau principal urmează a fi îndeplinite următoarele condiţii:

- ambele bunuri să fie în proprietatea aceluiaşi proprietar;

- titularul dreptului de proprietate trebuie să stabilească prin voinţa lui un raport cu destinaţia comună a ambelor bunuri.

Această regulă are caracter dispozitiv, admiţând posibilitatea ca părţile unui contract prin voinţa lor să deroge de la ea.

Bunul accesoriu urmează situaţia juridică a bunului principal dacă părţile nu convin altfel [5, art. 467 alin.(3)]. Ca urmare, dacă bunul principal va fi înstrăinat (vândut, schimbat, donat), această soartă o va avea şi bunul accesoriu, fiind şi el considerat înstrăinat. În situaţia de accesoriu se află toate raporturile de garanţie personală (fidejusiunea) şi reale (gajul).

Încetarea calităţii de bun accesoriu nu este opozabilă unuiterţ care a dobândit anterior drepturi privitoare la bunul principal [5, art. 467 alin. (4)]. E o precizare alin.(3), conform căruia bunul accesoriu urmează situaţia juridică a bunului principal.

Separarea temporară a unui bun accesoriu de bunul principal nu-i înlătură această calitate [5, art. 467 alin. (5)]. Dacă un bun accesoriu temporar este separat de la bunul principal, cu condiţia că ulterior îşi va lua locul de bun accesoriu a aceluiaşi bun principal, apoi el va rămâne a fi considerat că bun accesoriu respectiv fiindu-i aplicabile regulile respective.

Această clasificare prezintă interes în dreptul civil, deoarece bunul accesoriu urmează soarta juridică a bunului principal, dacă nu reiese altfel din lege sau din convenţia părţilor. Astfel, vânzarea unui instrument muzical implică obligaţia vânzătorului de a preda cumpărătorului şi cutia care este bun accesoriu, dacă părţile nu au convenit altfel $[15$, p. 45].

4.5. După felul cum pot fi sau nu înlocuite bunurile în executarea unei obligaţii, art.468 din CC distinge între bunurile fungibile şi bunurile nefungibile.

a) Bunurile fungibile sunt bunurile care, în executarea unei obligaţii, pot fi înlocuite cu altele fără a afecta valabilitatea plăţii. Toate celelalte bunuri sunt nefungibile [5, art.468 
alin. (1)]. Bunurile fungibile sunt bunuri determinate după număr, măsură sau greutate, ceea ce permite să fie înlocuite unele prin altele în executarea unei obligaţii. Ca regulă generală sunt fungibile bunurile de gen, adică acele bunuri care sunt determinabile prin numărare, măsurare, cântărire, determinare volumetrică şi sunt nefungibile bunurile certe [27].

b) Bunurile nefungibile sunt acelea care nu pot fi înlocuite cu altele în executarea unei obligaţii, aşa încât debitorul nu este liberat decât prin predarea bunului datorat [3, p. 79].

Fungibilitatea ori nefungibilitatea bunului este determinată de faptul dacă un bun poate fi înlocuit cu altul în cadrul executării unei obligaţiuni. De exemplu: $100 \mathrm{~kg}$ de grâu pot fi înlocuite cu $100 \mathrm{~kg}$ de grâu de aceeaşi calitate. Bunurile fungibile sunt acelea care pot fi înlocuite unele cu altele în executarea unei obligaţii. În schimb, bunurile nefungibile sunt acelea care nu se pot înlocui unele cu altele în executarea unei obligaţii, astfel că debitorul se va considera că a executat obligaţia doar în cazul în care a transmis bunul datorat [19, p. 339]. De exemplu, în categoria bunurilor fungibile putem enumera aşa bunuri ca: banii, alimentele de un anumit fel, mese, scaune, pixuri, caiete etc., iar la categoria bunurilor nefungibile aşa bunuri ca: o casă, un lot de pământ, un câine de rasă etc. Natura juridică a bunurilor fungibile presupune că ambele bunuri (care pot fi înlocuite în exercitarea unei obligaţii) au aceeaşi valoare pentru creditor din punct de vedere al plăţii datorate, aşa încât creditorului îi este indiferent care anume bun va primi.

Conform art.468 alin.(2) CC RM, „prin act juridic, un bun fungibil poate fi considerat nefungibil, iar un bun nefungibil poate fi considerat fungibil. Astfel, părţile unui act juridic pot prin voinţa lor să considere un bun fungibil ori nefungibil. Totuşi, privitor la unele bunuri cum sunt banii, cerealele sau altele vor fi considerate aproape întotdeauna fungibile. Fungibilitatea monedei este şi o necesitate practică, fiindcă de regulă este imposibil să întorci aceleaşi bancnote pe care le-ai primit ori să întorci aceeaşi materie primită" [19, p. 339].

Clasificarea făcută de text este prescrisă după criteriul posibilităţii bunurilor de a fi înlocuite unele cu altele în executarea unei obligaţii. Această clasificare prezintă importanţă în aprecierea valabilităţii plăţii şi determinarea momentului transmiterii (constituirii) dreptului real în actele juridice între vii translative (constitutive) de drepturi reale [26, p. 79].

4.6. După caracterul modului de determinare, distingem între bunuri certe, determinate individual (res certa) şi bunuri determinate generic (res genera).

Se consideră determinat individual bunul care, potrivit naturii sale, se individualizează prin semne, însuşiri caracteristice doar lui [5, art. 469 alin. (1)]. Astfel, bunul este determinat individual dacă se individualizează prin însuşirile proprii caracteristice doar lor (un tablou unic pictat de Picasso (Pablo Ruisy Picasso) - „Domnişoarele din Avignon”, o casă de locuit, un lot de teren). Deci, aceste bunuri se deosebesc de alte bunuri asemănătoare prin însuşirile lor specifice, care le fac în principiu unice [19, p. 339].

La fel, la această categorie se referă şi cele care se individualizează prin anticipaţie sau prin determinarea legii. Astfel, atribuim bunurile care care, deşi pot fi determinate generic, dar care prin convenirea părţilor la raport sau prin lege devin determinate individual. Ca exemplu: autoturismele care de fapt sunt bunuri determinate generic, însă legiuitorul impune atribuirea unor numere de înmatriculare (numere individuale), urmare la care acestea devin bunuri determinate individual [28, p. 123]. 
a) Bunul determinat generic se consideră „bunul care posedă semnele caracteristice tuturor bunurilor de acelaşi gen şi care se individualizează prin numărare, măsurare, cântărire. Bunul determinat generic este fungibil" [5, art. 469 alin. (2)].

Acel bun care se determină prin caracterele comune bunurilor de gen şi care se individualizează prin numărare (10 mese, 5 saune, 30 cărţi, 20 telefoane), măsurare (20 metri de stofă, $8 \mathrm{~m}$ de cablu electric), cântărire (5 kg de roşii, 1 tonă de mere). Deşi, după regula generală, bunurile determinate generic sunt considerate fungibile, totuşi, trebuie să ţinem cont de faptul că între aceste două categorii de bunuri nu întotdeauna există o perfectă identitate. Aşa de exemplu o carte este un bun generic şi totodată fungibil, adică poate fi înlocuită în executarea unei obligaţii cu o altă carte scrisă de acelaşi autor cu acelaşi conţinut. Însă pot exista cazuri când împrumutătorul va insista să fie întoarsă anume cartea împrumutată care poartă semnătura autorului (de exemplu prezentul Cod civil adnotat cu semnăturile tuturor autorilor comentariului) şi în aceste cazuri nu va mai fi vorba de un bun generic şi fungibil, ci de un bun determinat care îl deosebeşte de alte bunuri din această categorie [19, p. 339].

Totodată, prin act juridic, „bunurile determinate individual pot fi considerate determinate generic, iar bunurile determinate generic pot fi considerate determinate individual" [5, art. 469 alin. (3)].

Dacă însă bunul este generic, determinat numai prin caractere generice, atunci dreptul de proprietate se transmite la dobânditor după încheierea contractului, şi anume, de regulă la predarea bunului când se va proceda la individualizarea acestuia prin numărare, măsurare ori cântărire. Fără individualizare nu se poate opera transmiterea dreptului de proprietate, căci până atunci bunul vândut se confundă cu masa celorlalte bunuri identice ale proprietarului.

Importanţa aceste clasificări rezultă din modalitatea executării obligaţiei în ce priveşte aceste bunuri, aşa cum şi din situaţiile de legate de pieirea fortuită a bunului. Astfel, la pierirea fortuită a bunurilor determinate individual, debitorul nu poate fi obligat să transmită bunul. Acesta va fi obligat să compenseze valoarea acestui bun, pe când la pieirea fortuită a bunurilor determinate generic, debitorul este obligat să pună la dispoziţie creditorului un bun de acelaşi gen [28, p. 124].

4.7. După cum folosirea bunurilor implică sau nu consumarea substanței ori înstrăinarea lor, bunurile pot fi consumptibile sau neconsumptibile.

a) Bunurile consumptibile sunt acele bunuri a căror întrebuinţare obişnuită implică înstrăinarea sau consumarea substanţei lor [5, art. 470 alin. (1)]. Folosirea acestor bunuri nu se poate realiza decât consumându-se fie material, fie juridic prin înstrăinarea şi ieşirea lor din patrimoniu, într-un singur act de folosire. Includem în această categorie de bunuri produsele alimentare, materia primă, grânele, banii - acestea îndeplinindu-şi funcţiile sale prin înstrăinare. Bunurile consumptibile nu trebuie confundate cu bunurile comestibile, corelaţia dintre acestea fiind de gen - specie. Toate bunurile comestibile sunt şi bunuri consumptibile, însă nu toate bunurile consumptibile sunt şi bunuri comestibile (benzina, motorina sunt bunuri consumptibile, dar nu şi bunuri comestibile).

b) Bunurile neconsumptibile sunt acele care pot fi întrebuinţate în mod continuu fără a li se consuma substanţa lor sau să fie implicată înstrăinarea. Fac parte din această categorie aşa bunuri ca terenurile, construcţiile, automobilele etc. 
Prin act juridic, un bun consumptibil poate fi considerat neconsumptibil[5, art. 470 alin. (2)]. Astfel, pentru o librărie cărţile sunt bunuri consumptibile, căci aceasta nu le poate folosi decât înstrăinându-le, deşi prin natura lor ele sunt neconsumptibile. De asemenea, alimentele expuse în vitrină, în scop de reclamă, deşi consumptibile prin natura lor, devin prin această utilizare - neconsumptibile. fiind susceptibile de o întrebuinţare prelungită în timp [29, p. 68].

Clasificarea bunurilor în consumptibile şi neconsumptibile prezintă interes în materie de uzufruct şi împrumut. Astfel, uzufructul implică pentru uzufructuar dreptul de a se folosi de un bun fără a-i consuma substanţa, cu obligaţia de a-l restitui proprietarului la încetarea uzufructului.

Constituirea unui drept de uzufruct poate, aşadar, avea loc numai asupra unui bun neconsumptibil. În cazul în care se constituie un drept de uzufruct asupra unui bun consumptibil, uzufructuarul nu mai are obligaţia de a conserva substanţa bunului, ci poate dispune de el, cu îndatorirea de a restitui proprietarului un bun de aceeaşi cantitate, calitate şi valoare.

Bunurile consumptibile nu pot face obiectul unor acte juridice care implică îndatorirea de restituire a lucrului în individualitatea sa (cum sunt: comodatul, constituirea unui drept de uzufruct etc.), ci numai a actelor care îndreptăţesc la consumarea lucrurilor, cu obligaţia restituirii altora de acelaşi fel (cum sunt: împrumutul (ulei, zahăr), constituirea unui cvasiuzufruct etc.)[1, p. 256].

4.8. După calitatea titularului din al cărui patrimoniu fac parte, deosebim: bunuri ale domeniului public și bunuri ale domeniului privat.

Codul civil consacră art. 471 acestor categorii de bunuri. Temeiul acestei clasificări a bunurilor îl constituie art. 9 din Constituţie, care prevede că proprietatea este publică şi privată. În art. 471 alin. (1) se instituie o regulă foarte importantă, şi anume, statul şi unităţile administrativ-teritoriale au în proprietate două categorii de bunuri cu regim diferit: bunuri ale domeniului public şi bunuri ale domeniului privat. Această dispoziţie legală instituie prezumţia conform căreia bunul este considerat din domeniul privat dacă prin lege (şi numai prin lege) nu este atribuit categoriei bunuri publice. Bunurile statului şi cele ale unităţilor administrativ-teritoriale afectate domeniului privat pot circula liber, cu ele pot fi încheiate diferite acte juridice [7, p. 105].

a) Din domeniul public al statuluisau al unităţilor administrativ-teritoriale fac parte bunurile determinate de lege, precum şi bunurile care, prin natura lor, sunt de uz sau de interes public. Interesul public implică afectarea bunului la un serviciu public sau la orice activitate care satisface nevoile colectivităţii fără a presupune accesul nemijlocit al acesteia la utilizarea bunului conform destinaţiei menţionate [5, art. 471 alin. (2)]. Bunurile domeniului public sunt inalienabile, insesizabile şi imprescriptibile. Dreptul de proprietate asupra acestor bunuri nu se stinge prin neuz şi nu poate fi dobândit de terţi prin uzucapiune.

Pentru ca bunul să fie afectat domeniului public este necesar ca prin lege să fie numite care anume bunuri sunt considerate bunuri publice, ori natura bunului să fie de uz public sau de interes public.

„Bogăţiile de orice natură ale subsolului, spaţiul aerian, apele şi pădurile folosite în interes public, resursele naturale ale zonei economice şi ale platoului continental, căile de 
comunicaţie, precum şi alte bunuri stabilite de lege, fac obiectul exclusiv al proprietăţii publice" [5, art. 471 alin.(3)].

Constituția RM, în art. 127, alin. (4) prevede: „Bogăţiile de orice natură ale subsolului, spaţiul aerian, apele şi pădurile folosite în interes public, resursele naturale ale zonei economice şi ale platoului continental, căile de comunicaţie, precum şi alte bunuri stabilite de lege, fac obiectul exclusiv al proprietăţii publice".

Astfel, conform prevederilor art. 56 Cod Funciar [20], terenurile destinate ocrotirii naturii (terenurile rezervaţiilor, parcurilor naţionale, parcurilor dendrologice şi zoologice, grădinilor botanice, braniştilor, monumentelor naturii, terenurile zonelor de protecţie şi zonelor sanitare) sunt prin exclusivitate proprietate a statului.

Legea privind delimitarea proprietăţii publice [30], în art. 5 prevederegimul juridic al bunurilor domeniului public. Astfel, bunurile domeniului public formează obiectul exclusiv al proprietăţii publice a statului sau a unităţilor administrativ-teritoriale și sunt inalienabile, insesizabile și imprescriptibile, circuitul civil al acestora fiind limitat în condiţiile legii.

Bunurilor domeniului public le sunt caracteristice următoarele [30, art. 5 alin. (2)]:

- $\quad$ nu pot fi înstrăinate sau depuse în capitalul social al unor persoane juridice;

- $\quad$ nu pot fi supuse urmăririi silite;

- nu pot fi incluse în masa debitoare în cazul insolvabilităţii/falimentului persoanei juridice;

- $\quad$ nu pot fi obiectul unei garanţii reale;

- $\quad$ nu pot fi dobândite de persoane fizice sau juridice prin uzucapiune.

A două categorie de bunuri care face parte din domeniul public sunt bunurile care, prin natura lor, sunt de uz sau de interes public.

Bun de interes local este bunul proprietate publică a unităţii administrativ-teritoriale din domeniul public, care serveşte cauzei de utilitate publică locală.

Bun de interes naţional - este bunul proprietate publică a statului din domeniul public, care serveşte cauzei de utilitate publică naţională.

Sunt de uz public bunurile accesibile tuturor persoanelor, cum ar fi parcurile naturale, străzile, piețele etc. Sunt de interes public bunurile care deşi nu pot fi folosite de orice persoană, au destinaţ̧ia de a fi folosite în cadrul unor activităţi care interesează pe toţi membrii societăţii cum ar fi muzeele, teatrele, şcolile etc.

b) Bunuri ale domeniului privat sunt bunurile care aparţin persoanelor fizice sau persoanelor juridice, inclusiv statului şi unităţilor administrativ-teritoriale, şi care sunt alienabile, prescriptibile şi sesizabile [7, p. 105].

Bunurile care aparţin statului sau unităţilor administrativ-teritoriale fac parte din domeniul privat dacă, prin lege sau în modul stabilit de lege, nu sunt trecute în domeniul public[5, art. 471 alin. (1)].

Bunurile domeniului privat al statului şi al unităţilor administrativ-teritoriale sunt alienabile, sesizabile și prescriptibile și pot fi obiectul oricărui act juridic civil conform procedurilor stabilite, cu excepţia unor categorii de bunuri al căror circuit civil este limitat în mod expres prin lege [30, art. 6 alin. (1)].

Nu se permite transmiterea cu titlu gratuit către persoanele fizice sau persoanele juridice de drept privat a bunurilor domeniului privat al statului și al unităţii administrativteritoriale, cu excepţia cazurilor în care aceste bunuri:

- se înstrăinează cu titlu gratuit persoanelor fizice pentru lichidarea consecinţelor calamităţilor naturale printr-o hotărâre a Guvernului, în cazul bunurilor proprietate publică 
a statului, sau prin decizia autorității deliberative a administrației publice locale, în cazul bunurilor proprietate publică a unității administrativ-teritoriale;

- reprezintă terenuri ce se atribuie persoanelor fizice pentru construcţia de case individuale în condiţiile prevăzute de lege;

- reprezintă bunuri destinate creării parcurilor industriale, conform prevederilor Legii nr. 182/2010 cu privire la parcurile industriale;

- sunt în folosinţa comună a membrilor condominiului.

Această clasificare a bunurilor prezintă importanţă deosebită, întrucât numai bunurile din domeniul public (al statului sau al unităţilor administrativ-teritoriale) sunt inalienabile şi, pe cale de consecinţă, insesizabile şi imprescriptibile. De altfel, dreptul de proprietate asupra acestor bunuri nu se stinge prin neuz şi nu poate fi dobândit de terţi prin uzucapiune. În schimb, art. 6 alin. (1) a Legii privind delimitarea proprietăţii publice stabileşte că „bunurile domeniului privat al statului şi al unităţilor administrativ-teritoriale sunt alienabile, sesizabile și prescriptibile și pot fi obiectul oricărui act juridic civil conform procedurilor stabilite, cu excepţia unor categorii de bunuri al căror circuit civil este limitat în mod expres prin lege".

\subsection{Universalitatea de fapt}

Potrivit art. 472 alin. (1) CC RM „constituie o universalitate de fapt ansamblul bunurilor care aparțin aceleiași persoane și sunt privite ca un tot întreg prin voința acesteia sau prin lege”.

Universalitatea de fapt constituie o totalitate de lucruri corporale omogene care sunt considerate ca un tot întreg (o bibliotecă, o turmă, un set de veselă, un set de mobilă etc.). Valoarea economică a acestei universalităţi trebuie pusă în legătură cu reunirea elementelor constitutive. Un exemplu al unei universalităţi de fapt poate servi alin. (2) al art. 618 din Codul civil care prevede că „arborii care se scot din pepinieră fără degradarea acesteia nu fac parte din uzufruct decât cu obligaţia uzufructuarului de a se conforma dispoziţiilor legale şi uzanţelor locale în ceea ce priveşte înlocuirea lor”. Deci, pepiniera se consideră că o universalitate din care fac parte arbori tineri care se cresc pentru a fi vânduţi sau transplantaţi. Utilitatea lor este dată de ansamblul pe care îl formează. Universalităţile de fapt sunt, în principiu, fracţiuni de patrimoniu şi se deosebesc, în esenţă, de patrimoniu prin aceea că în sânul lor nu funcţionează relaţia activ-pasiv. Cu toate acestea, universalitatea de fapt nu poate fi considerată identică cu patrimoniul. Importanţa universalităţii de fapt constă în faptul că în caz de înstrăinare vânzare-cumpărare, sechestru, gaj, universalitatea va fi privită în bloc şi nu separat pentru fiecare bun ce formează tot întregul - universalitatea [19, p. 341 - 342].

Bunurile care alcătuiesc universalitatea de fapt pot, împreună sau separat, să facă obiectul unor acte sau raporturi juridice distincte [5, art. 472 alin. (2)].

Universalitate de drept la fel constituie o pluralitate de bunuri, numai că în acest caz, în componenţa universalităţii de drept pot intra nu numai bunurile corporale, ci şi incorporale, care privite împreună sunt considerate ca un tot întreg. Ca universalitate de drept este considerat patrimoniul.

4.10. După cum sunt ori nu producătoare de alte bunuri, fără a li se consuma sau diminua substanţa, bunurile se împart în frugifere şi nefrugifere.

a) Bunurile frugifere sunt acelea care, în mod periodic şi fără consumarea substanţei lor, dau naştere altor bunuri, numite fructe [26, p. 81]. 
b) Bunurile nefrugifere sunt acelea care nu au însuşirea de a da naştere altor produse, în mod periodic şi fără consumarea substanţei lor.

Codul civil clasifică produsele bunurilor în fructe și producte.

Fructele reprezintă acele produse care derivă din folosirea unui bun, fără a diminua substanța acestuia.

Productele sunt produsele obținute dintr-un bun cu consumarea sau diminuarea substanței acestuia, precum copacii unei păduri, piatra dintr-o carieră și altele asemenea.

Pornind de la prevederile înscrise în art. 473 CC RM, vom distinge trei categorii de fructe:

- fructe naturale: sunt produsele directe și periodice ale unui bun, obținute fără intervenția omului, cum ar fi acelea pe care pământul le produce de la sine, producția și sporul animalelor [5, art. 473 alin. (3)];

- fructe industriale: sunt produsele directe şi periodice ale unui bun, obţinute ca rezultat al intervenţiei omului, cum ar fi recoltele de orice fel [5, art. 473 alin. (4)];

- fructe civile (numite și venituri): sunt veniturile rezultate din folosirea bunului de către o altă persoană în virtutea unui act juridic, precum sunt chiriile, arendele, dobânzile, venitul rentelor și dividendele [5, art. 473 alin. (5)].

Distincţia dintre cele trei categorii de fructe prezintă interes în ceea ce priveşte modul lor de dobândire, în sensul că fructele naturale şi cele industriale se dobândesc prin culegere (percepere), la data separării de bunul care le-a produs [5, art. 474 alin. (2)], iar fructele civile se dobândesc zi cu zi (prin simpla scurgere a timpului) [5, art. 474 alin. (3)].

De exemplu, în materia dreptului de uzufruct, fructele neculese în momentul deschiderii dreptului la uzufruct sunt ale uzufructuarului, iar cele neculese la sfârşitul perioadei de uzufruct sunt ale nudului proprietar dacă actul prin care s-a instituit uzufructul nu prevede altfel. Veniturile se consideră percepute zi cu zi şi se cuvin uzufructuarului proporţional duratei uzufructului său. Aceste prevederi sunt aplicabile arenzii, chiriei imobilelor, dividendelor şi dobânzilor obţinute [5, art. 612 alin. (2)].

Distincţia dintre fructe şi producte are importanţă practică sub mai multe aspecte, de exemplu: uzufructuarul are dreptul numai la fructe, nu şi la producte, care se cuvin nudului proprietar (art. 618-619 CC); posesorul de bună-credinţă dobândeşte numai fructele (art. 497 CC RM), nu însă şi productele.

Importanţa acestei clasificări rezultă din următoarele:

- modul de dobândire a lor este diferit. Fructele naturale şi industriale se dobândesc prin culegere, fructele civile se dobândesc zi de zi, iar productele se dobândesc prin separarea lor.

- în materie de uzufruct, de regulă fructele se culeg sau percep de uzufructuar, iar productele de către nudul proprietar.

- în materia efectelor posesiunii posesorul de bună credinţă dobândeşte fructele, iar productele aparţin nudului proprietar.

\subsection{Conținutul digital și bunul digital}

Reforma Codului civil, în vigoare din 1 martie 2019, introduce conceptul de conținut digital și bun digital prin articolul 477 al Codului civil. Observăm că articolul 455 Cod civil nu este supus la careva modificări și, tradițional, conceptul de bun rămâne să cuprindă lucrurile și drepturile patrimoniale. Așadar, un bun întotdeauna are context patrimonial, fie materializat prin lucru sau sub forma unui drept real sau de creanță. Acest context trezește interes față de calificarea juridică a bunului digital în raport cu noțiunea clasică a bunului și 
impactul juridic pe care noua instituție a bunului digital îl poate avea la exercitarea drepturilor civile [31].

Potrivit art. 477 alin. (1) CC RM, „conținut digital se consideră datele produse și livrate în formă digitală, cum sunt programele de calculator, aplicațiile, jocurile, muzica, înregistrările video sau textele, indiferent dacă sunt accesate prin descărcare sau prin flux continuu, de pe un suport material sau prin orice alte mijloace".

Dacă un conținut digital este livrat pe un suport material, cum sunt CD-urile sau DVD-urile, lui i se aplică dispozițiile privind bunurile corporale.

Conform textului art. 477 alin. (3) CC, condițiile de existență a unui bun digital sunt următoarele [31]:

- existența unui conținut digital sau a unui cont la o poştă electronică, la o reţea sau alt cont online;

- persoana are dreptul la acel conținut digital sau la poşta electronică, la reţeaua sau alt cont online.

Custodele bunului digital este profesionistul care oferă acces, menține, procesează, primește sau păstrează bunul digital al unei alte persoane (utilizator), conform contractului dintre custode și utilizator [5, art. 477 alin. (4)].

Utilizatorul poate folosi serviciul electronic oferit de custodele bunului digital pentru a ordona custodelui să ofere acces sau să nu ofere acces la toate sau anumite bunuri digitale, inclusiv la conținutul comunicărilor electronice. Dacă serviciul respectiv oferit de custode permite utilizatorului să modifice sau să revoce un ordin în orice moment, ordinul privind oferirea accesului are prioritate față de voința exprimată de utilizator într-un testament sau într-un mandat [5, art. 478 alin. (1)].

Dacă utilizatorul nu a folosit serviciul prevăzut de alin.(1) sau dacă custodele nu oferă un asemenea serviciu, utilizatorul poate permite sau interzice, printr-un testament sau mandat, accesul anumitor persoane determinate sau determinabile la toate sau anumite bunuri digitale [5, art. 478 alin. (2)].

Ordinul dat de utilizator are prioritate față de condițiile contractului dintre custode și utilizator. În absența unui ordin al utilizatorului, se aplică condițiile contractului dintre custode și utilizator, care pot permite, limita sau exclude accesul terților interesați de bunurile digitale ale utilizatorului.

În cazul în care în privința utilizatorului a fost instituită o măsura de ocrotire judiciară, iar ocrotitorul provizoriu, curatorul sau tutorele nu are acces la bunurile digitale ale persoanei ocrotite, el poate cere de la instanța de judecată să-i fie acordat dreptul la acces dacă are un interes legitim în acest sens și dacă aceasta nu contravine dorințelor și sentimentelor exprimate în trecut și prezent de către persoana ocrotită. În aceleași condiții, instanța de judecată poate acorda dreptul la acces prin hotărârea judecătorească prin care se instituie măsura de ocrotire judiciară [5, art. 478 alin. (4)].

Custodele care trebuie să ofere acces la bunurile digitale, îl poate oferi prin următoarele [5, art. 478 alin. (5)]:

A) acces deplin la contul online;

B) acces parțial la contul online, dar suficient pentru a respecta împuternicirile persoanei îndreptățite;

C) furnizarea către persoana îndreptățită a copiilor, pe un suport durabil, de pe bunurile digitale pe care utilizatorul le-ar fi putut accesa. 
Custodele poate stabili o taxă rezonabilă pentru a acoperi costurile de procesare a cererii și de oferire a accesului.

Custodele nu este obligat să ofere acces la bunurile digitale șterse de către utilizator.

4.12. După modul lor de percepere, bunurile pot fi corporale și necorporale.

Codul civil nu cuprinde o normă expresă dedicată bunurilor corporale și bunurilor incorporale, așa cum o face în cazul bunurilor descrise mai sus. $O$ asemenea clasificare însă poate fi dedusă din conținutul art.455, care prevede că bunuri sunt toate lucrurile susceptibile apropierii individuale sau colective și drepturile patrimoniale [7, p. 107 - 108].

a) Bunurile corporale sunt acele bunuri care au o existenţă materială, fiind uşor perceptibile simţurilor omului. Sunt bunuri corporale lucrurile care pot fi în formă solidă, lichidă sau sub formă de gaze (un teren, o casă, un automobil, motorina, gazele naturale [6, p.108] conținut digital este livrat pe un suport material [5, art. 477, alin. (2)] etc.

b) Bunurile incorporale sunt valorile economice care au existenţă ideală, abstractă. Sunt astfel de bunuri drepturile subiective patrimoniale. Doctrina juridică distinge următoarele categorii de bunuri incorporale:

- drepturile reale, altele decât dreptul de proprietate;

- proprietăţile incorporale. În această categorie sunt incluse bunuri a căror existenţă depinde de activitatea şi de puterea creatoare a omului, fie dintr-o activitate în curs, fie dintr-o activitate trecută şi materializată în creaţii spirituale (drepturile de proprietate industrială, drepturile de autor şi drepturile conexe acestora);

- titlurile de valoare. În această categorie sunt incluse valorile mobiliare (acţiunile, obligaţiunile, instrumentele financiare derivate sau orice alte titluri de credit încadrate de Comisia Naţională a Valorilor Mobiliare în această categorie), precum şi efectele de comerţ (cambia, biletul la ordin şi cecul);

- drepturile de creanţă. În literatura juridică mai veche se sublinia că împărţirea bunurilor în corporale şi incorporale echivalează cu opunerea dreptului de proprietate, pe de o parte, celorlalte drepturi reale şi drepturilor de creanţă, pe de altă parte [3, p. 82].

Clasificarea bunurilor în corporale şi incorporale prezintă importanţă sub următoarele aspecte:

- dobândirea proprietăţii asupra bunurilor mobile ca efect al posesiei de bunăcredinţă [5, art. 527] vizează numai bunurile mobile corporale,iar numai in mod excepţional şi unele bunuri mobile incorporale,anume titlurile la purtător [5, art. 490];

- dobândirea proprietăţii prin simpla tradiţiune (remitere) se aplică numai în privinţa bunurilor mobile corporale şi, prin excepţie, a titlurilor lapurtător;

- regimul de drept internaţional privat diferă, după distincţiile cuprinse în Cartea a V-a a Codului civil.

\subsection{Bunurile culturale mobile}

În noile modificări ale CC RM au fost incluse la art. 481 această noua categorie de bunuri. Nu că aceste bunuri sunt noi in legislaţia RM, dar noi sunt in legea civilă. Astfel, sunt bunuri culturale mobile bunurile atribuite, în condițiile legii, la patrimoniul cultural național mobil al Republicii Moldova, precum și bunurile atribuite ca atare de legea aplicabilă regimului juridic al bunului respectiv conform regulilor dreptului internațional privat.

Bunurile culturale mobile care aparțin Republicii Moldova sau unei unități administrativ-teritoriale fac parte din domeniul public al acesteia. 
Regimul juridic al bunurilor culturale mobile, precum și condițiile și limitele în care persoanele fizice și juridice exercită dreptul de proprietate asupra acestora sunt prevăzute de lege, de tratatele internaționale la care Republica Moldova este parte și, în completare, de prezentul cod. Dispozițiile se bazează pe cadrul creat de Legea nr. 280 din 27 decembrie 2011 privind protejarea patrimoniului cultural naţional mobil [32]. În sensul acestei legi, patrimoniu cultural naţional mobil este ansamblu de bunuri culturale mobile, clasate în patrimoniul cultural naţional cu valoare deosebită sau excepţională istorică, arheologică, documentară, etnografică, artistică, ştiinţifică şi tehnică, literară, cinematografică, numismatică, filatelică, heraldică, bibliofilă, cartografică, epigrafică, estetică, etnologică şi antropologică, reprezentând mărturii materiale ale evoluţiei mediului natural şi ale relaţiei omului cu acest mediu, ale potenţialului creator uman şi ale contribuţiei naţionale la civilizaţia universală.

Astfel, conform prevederilor articolului 4 al Legii, patrimoniul este format din următoarele bunuri cultural mobile:

\section{1). bunurile arheologice şi istorico-documentare precum:}

a) piese arheologice din săpături terestre şi subacvatice sau din descoperiri întâmplătoare, cu excepţia eşantioanelor de materiale de construcţie, de materiale din situri, care constituie probe arheologice pentru analize de specialitate;

b) inscripţii, elemente separate provenite din dezmembrarea monumentelor istorice;

c) mărturii materiale şi documentare privind istoria politică, economică, socială, militară, religioasă, ştiinţifică, artistică, sportivă sau din alte domenii;

d) manuscrise, incunabule, cărţi rare şi cărţi vechi, publicaţii de diferite tipuri, cu autografe şi ex-librisuri, periodice;

e) documente şi tipărituri de interes social: documente de arhivă, hărţi şi alte materiale cartografice;

f) obiecte cu valoare memorialistică;

g) obiecte şi documente cu valoare numismatică, filatelică, heraldică: monede, medalii, decoraţii, insigne, bancnote, sigilii, brevete, mărci poştale, drapele şi stindarde;

h) piese epigrafice;

i) fotografii, clişee fotografice, filme, înregistrări audio şi video;

j) instrumente muzicale;

k) uniforme militare şi accesorii la ele;

l) vestimentaţie;

\section{2) bunurile cu semnificaţie artistică precum:}

a) opere de artă plastică: pictură, sculptură, grafică, desen, gravură, stampă şi altele asemenea;

b) opere de artă decorativă şi aplicată: mobilier, tapiserii, covoare, piese din sticlă, ceramică, metal, lemn, textile şi din alte materiale, podoabe;

c) obiecte de cult: icoane, broderii, orfevrărie, mobilier şi altele;

d) proiecte şi prototipuri de design;

e) materiale primare ale filmelor artistice, documentare şi de animaţie;

f) monumente de for public, componente artistice expuse în aer liber;

g) cărţi poştale şi ilustraţii;

h) piese decorative pentru spectacole; 
3) bunurile cu semnificaţie etnografică precum:

a) elemente de arhitectură populară;

b) elemente din instalaţii tehnice;

c) obiecte de uz casnic şi gospodăresc;

d) unelte de muncă;

e) produse ale industriei casnice textile: covoare, păretare, prosoape, costume populare şi altele asemenea;

f) mobilier;

g) recuzită a obiceiurilor;

h) obiecte de cult;

i) produse de artizanat contemporan;

4) bunurile de importanţă ştiinţifică precum:

a) specimene rare şi colecţii de zoologie, botanică, mineralogie, petrologie, paleontologie, antropologie, speologie, anatomie;

b) trofee de vânat;

5) bunurile de importanţă tehnică precum:

a) creaţii tehnice de unicat;

b) rarităţi, indiferent de marcă;

c) prototipuri ale aparatelor, dispozitivelor şi maşinilor de creaţie curentă;

d) orologerie;

e) realizări ale tehnicii populare;

f) documente tehnice: proiecte, planuri, schiţe, brevete de invenţii;

g) mijloace de transport şi de telecomunicaţii;

h) matriţe de $C D$-uri, $C D-R O M, D V D$;

6) bunurile cu semnificaţie memorialistică precum:

a) bunuri şi obiecte memoriale;

b) documente şi fotografii din viaţa personalităţilor;

c) piese legate de evenimente de importanţă naţională şi internaţională.

4.14.Conform art.476 alin.(1) C.civ., „se consideră obiect de proprietate intelectuală orice rezultat al activității intelectuale, confirmat și protejat prin drepturile corespunzătoare privind utilizarea acestuia".

Rezultatele activităţii intelectuale, atributele de identificare a persoanei juridice, mijloacele de individualizare a producţiei, a lucrărilor executate sau a serviciilor prestate sunt considerate ca obiecte nepatrimoniale, purtând caracterele drepturilor personale nepatrimoniale. Natura juridică a acestor categorii de drepturi determină şi particularităţile reglementării şi apărării lor [1, p. 268].

Obiectele de proprietate intelectuală se divizează în două categorii [5, art. 476 alin. $(2)]$ :

a) obiecte de proprietate industrială (invenții, soiuri de plante, topografii de circuite integrate, mărci, desene și modele industriale, indicații geografice, denumiri de origine și specialități tradiționale garantate);

b) obiecte ale dreptului de autor (opere literare, artistice și științifice etc.) și ale drepturilor conexe (interpretări, fonograme, videograme și emisiuni ale organizațiilor de difuziune etc.). 
De domeniul proprietății intelectuale țin și alte bunuri ce dispun de un sistem de reglementare separat, cum ar fi:

a) secretul comercial (know-how);

b) numele comercial.

În cazul obiectelor de proprietate industrială, dreptul asupra acestora apare în urma înregistrării obiectului, a acordării titlului de protecție de către oficiul național de proprietate intelectuală sau în alte condiții prevăzute de legislația națională, precum și în baza tratatelor internaționale la care Republica Moldova este parte. În cazul obiectelor dreptului de autor și ale drepturilor conexe, înregistrarea nu este o condiție obligatorie pentru apariția și exercitarea drepturilor respective, aceste obiecte fiind protejate din momentul creării lor [5, art. 476 alin. (4)].

În condițiile legii, titularul dreptului asupra obiectului de proprietate intelectuală:

a) poate înstrăina dreptul prin cesiune;

b) poate permite exploatarea lui de către terți prin licență exclusivă sau neexclusivă;

c) poate exercita alte drepturi morale și patrimoniale prevăzute de lege în privința obiectului dreptului exclusiv [5, art. 476 alin.(5)].

Cu excepțiile prevăzute de lege, nicio persoană nu poate exploata dreptul asupra obiectului de proprietate intelectuală al altuia fără licența corespunzătoare. Licența se prezumă neexclusivă dacă nu s-a prevăzut expres contrariul.

Dreptul asupra obiectului de proprietate intelectuală și dreptul acordat prin licență se consideră bunuri incorporale și pot fi grevate cu drepturi reale limitate în folosul terților [5, art. 476 alin. (7)].

În articolul de faţă sunt cuprinse reglementări cu caracter general referitor la rezultatele activităţii intelectuale ale persoanei fizice sau persoanei juridice. De aceea, reglementările propriu zise ale acestor drepturi personale nepatrimoniale le găsim în alte acte normative. Unul din aceste acte este Legea privind dreptul de autor şi drepturile conexe [33], care reglementează raporturile ce apar la crearea şi valorificarea operelor literare, artistice şi ştiinţifice (dreptul de autor), a interpretărilor, fonogramelor, videogramelor şi emisiunilor organizaţiilor de difuziune (drepturi conexe), precum şi alte drepturi care sunt recunoscute în legătură privind activitatea intelectuală din domeniul literaturii, artei şi ştiinţei.

De asemenea, reglementări referitoare la dreptul de autor, cât şi la protecţia acestuia întâlnim în următoarele acte normative:

- Codul penal al RM nr.985 din 18.04.2002. În Monitorul Oficial nr.72-74 din 14.04.2009 (art.1851. Încălcarea dreptului de autor şi a drepturilor conexe, art.1853. Declaraţiile intenţionat false în documentele de înregistrare ce ţin de protecţia proprietăţii intelectuale);

- Codul contravențional al RM nr.218 din 24.10.2008. În Monitorul Oficial nr.78-84 din 17.03.2017 (art.96. Încălcarea dreptului de autor şi a drepturilor conexe);

- Legea cu privire la Agenţia de Stat pentru Proprietatea Intelectuală nr.114 din 0307-2014. În Monitorul Oficial nr.282-289 din 26-06-2014;

- Legea privind protecţia mărcilor nr.38 din 29-02-2008. În Monitorul Oficial nr.99101 din 06-06-2008;

- Legea privind protecţia desenelor şi modelelor industriale nr.161 din 12-07-2007. În Monitorul Oficial nr.136-140 din 31-08-2007; 
- Hotărârea Guvernului nr.89 din 10-02-2012 pentru aprobarea Regulamentului cu privire la înregistrarea obiectelor dreptului de autor şi drepturilor conexe. În Monitorul Oficial nr.34-37 din 17-02-2012;

- Hotărârea Guvernului nr.641 din 12-07-2001 despre tarifele minime ale remuneraţiei de autor. În Monitorul Oficial nr.81-83 din 20-07-2001.

De asemenea, menţionăm că Republica Moldova este parte a mai multor convenţii internaţionale, printre care:

- Convenţia pentru constituirea Organizaţiei Mondiale pentru Protecţia Proprietăţii Intelectuale (OMPI), adoptată la Stokholm la 14 iulie 1967 (data aderării - 25 decembrie 1991);

- Convenţia de la Berna privind protecţia operelor literare şi artistice (Actul de la Paris din 24 iulie 1971, modificat la 28 septembrie 1979) (data aderării - 2 noiembrie 1995);

- Convenţia internaţională pentru ocrotirea drepturilor interpreţilor, producătorilor de fonograme şi ale organizaţiilor de diviziune, adoptată la Roma la 26 octombrie 1961 (data aderării - 5 decembrie 1995);

- Convenţia Universală cu privire la dreptul de autor, adoptată la Geneva la 6 septembrie 1952 - în acţiune pe teritoriul republicii de la data aderării la Convenţie a Uniunii Sovietice (27 mai 1973), din competenţa căreia s-a deprins Republica Moldova [1, p. $270-271]$.

5. Concluzii finale.Scopul prezentului studiu a constat în studierea bunurilor ca o varietate de obiecte ale raporturilor juridice civile, specificul poziției lor în sistemul obiectelor și particularitățile regimului lor juridic pentru a clarifica prevederile teoretice și a elabora recomandări practice în acest sens.

Importanța clasificării bunurilor în dreptul civil rezidă în atribuirea unui regim juridic specific fiecărui tip de bun, în dependență de semnificația și de problemele care apar în jurul lor.

Caracteristicile regimului juridic al bunurilor le oferă unicitate, care constă în faptul că proprietățile sale tipice nu acționează ca niște reguli speciale, diferite de cele de bază.

Astfel, trăsăturile regimului bunurilor în sine sunt baza, arhetipul, prototipul regimurilor tuturor celorlalte obiecte ale dreptului civil.

În consecință, studiul stării juridice a bunurilor, clasificarea acestora ca una dintre pietrele de temelie ale universului juridic, nu își va pierde niciodată relevanța. În orice caz, va fi atât timp cât umanitatea continuă să se separe de lumea din jur, atâta timp cât o persoană există în lumea lucrurilor.

\section{Bibliografia}

1. Ursu V., Chiriac N. Dreptul civil. Introducere: Manual. Chişinău: Tehnica-UTM, 2020. - 492 p.

2. Dicționar juridic LegeAZ. https://legeaz.net/dictionar-juridic/obiectul-raportului-juridic-civil (vizitat la 10.07.2019).

3. Boroi G. Drept civil. Partea generală. Persoanele. Bucureşti: ALL BECK, 2001. - 296 p.

4. Bîtcă I. Note de curs. Drept civil. Partea generală. Chișinău, 2013. - 124 p.

5. Codul Civil al R.Moldova nr.1107 din 06.06.2002. Republicat în Monitorul Oficial nr.66-75 din 01.03.2019 art.132.

6. Turianu C. Curs de drept civil. Craiova: Universitară, 2005. - 247 p.

7. Baieș S., Roșca N. Drept civil. Partea generală. Persoana fizică. Persoana juridică. Vol.1. Chișinău: Cartier, 2004. $-400 \mathrm{p}$. 
8. Bunurile -definitia bunurilor https://www.stiucum.com/drept/drept-civil/Bunurile-definitiabunurilor33758.php (vizitat la 12.02.2021)

9. Красавчикова Л.О. Понятие и система личных неимущественных прав граждан в гражданском праве РФ. Москва, 1994. - 435 с.

10. Малеин М.Н. Личные неимущественные права граждан: понятие, осуществление, защита. Москва: М3 Пресс, 2001. - $244 \mathrm{c}$.

11. Legea privind transplantul de organe, ţesuturi şi celule umane nr.42 din 06.03.2008. În: Monitorul Oficial nr.81 $\operatorname{din} 25.04 .2008$.

12. Codul penalal RM nr.985 din 18.04.2002. În: Monitorul Oficial nr.72-74 din 14.04.2009.

13. Charrier Jean-Loup, Chiriac A.. Codul Convenției Europene a Drepturilor Omului. Chișinău: Balacron, 2008. $724 \mathrm{p}$.

14. Legea cu privire la arme nr.130 din 08.06.2012. În: Monitorul Oficial nr. 222-227 din 26-10-2012.

15. Pușcă Andy, Costache Mirela. Drept civil. Partea generală. Anul I, semestrul I. Galați: Universitatea Danubis, 2010. - 115 p.

16. Codul contravenționalal RM nr.218 din 24.10.2008. În: Monitorul Oficial nr. 78 - 84 din 17.03.2017.

17. Palii A. Dicţionar explicativ al limbii române. Chișinău: Epigraf, 2009. - 2280 p.

18. Nota informativă la proiectul Legii privind modificarea şi completarea Cărţii I a Codului Civil al Republicii Moldova, 2016,

http://justice.gov.md/public/files/transparenta_in_procesul_decizional/coordonare/2017/aprilie/Nota_infor mativ_proiect_amendare_Cod_civil_xxxxxxx.pdf.

19. Antohi L., Baieş S., Băieşu A. ș.a. Comentariul Codului Civil al R. Moldova. Chişinău: Tipografia Centrală, 2006. - 1265 p.

20. Codul funciar al RM, adoptat prin Legea nr.828 din 25.12.1991 // Republicat în M.0. nr.107 din 04.09.2001.

21. Legea cadastrului bunurilor imobile nr.1543 din 25.02.1998. În: Monitorul Oficial al Republicii Moldova nr.44-46 din 21.05.1998.

22. Legea nr.354-XV din 28.10.2004 cu privire la formarea bunurilor imobile. În: Monitorul Oficial al Republicii Moldova, 2004, nr.233-236.

23. Codul fiscal al RM nr. 1163 din 24.04.1997, republicat în Monitorul Oficial al Republicii Moldova. Ediţie Specială, 08 februarie 2007, p.4.

24. Ungureanu Carmen Tamara. Drept Civil. Suport de curs http://jurnalulsportivului.files.wordpress.com/2012/02/drept-civil-an-i-sem-i-conf-dr-carmen-tamaraungureanu.pdf.

25. Diaconu Constantin, Firică Cristian. Drept civil. Partea generală. Persoanele. Curs în tehnologie ID/IFR. Bucureşti: Editura Fundaţiei România de Mâine, 2014. - 360 p.

26. Boroi G., Anghelescu C.A. Curs de drept civil. Partea generală. Bucureşti: Hamangiu, 2012. - 422 p.

27.Jora Cristian. Unele consideraţii cu privire la clasificarea bunurilor conform reglementărilor Noului Cod Civil. http://cogito.ucdc.ro/2012/vol4n1/ro/10_uneleconsideratiicuprivirelaclasificareabunurilorcristianjora.pdf (accesat: 03.04.2020).

28. Trofimov I. Dreptul civil. Introducere în dreptul civil, Academia Ştefan cel Mare a MAI, ed. Adriga Vis, Chişinău S. n., 2020, 250 p.

29. Lupulescu D. Drept civil. Introducere în dreptul civil. București: Lumina Lex, 1998. - 239 p.

30. Legea privind delimitarea proprietăţii publice nr.29 din 05.04.2018. În: Monitorul Oficial nr.142-148 din 04.05.2018.

31. Palamarciuc V. Bunul digital - inovația și dilemele juridice în reforma Codului Civil din Republica Moldova. https://juridicemoldova.md/3086/bunul-digital-inovatia-si-dilemele-juridice-reforma-codului-civil-dinrepublica-moldova.html (accesat: 03.04.2020).

32. Legea privind protejarea patrimoniului cultural naţional mobil nr. 280 din 27-12-2011. În: Monitorul Oficial nr. 82-84 din 27.04.2011.

33. Legea privind dreptul de autor și drepturile conexe nr. 139 din 02.07.2010. În: Monitorul Oficial nr. 191 - 193 din 01.10.2010. 